\title{
Control of cyclic AMP concentration in bovine endometrial stromal cells by arachidonic acid
}

\author{
Z Cheng, E L Sheldrick, E Marshall, D C Wathes ${ }^{1}$, D R E Abayasekara ${ }^{1}$ and A P F Flint \\ School of Biosciences, University of Nottingham, Sutton Bonington Campus, Loughborough LE12 5RD, UK and \\ ${ }^{1}$ Reproduction, Genes and Development Group, Royal Veterinary College, Hawkshead Lane, North Mymms, \\ Hatfield, Herts AL9 7TA, UK
}

Correspondence should be addressed to A P F Flint; Email: anthony.flint@nottingham.ac.uk

Z Cheng is now at Laboratory of Stem Cell Biology, Institute of Biochemistry and Cell Biology, Shanghai Institutes for Biological Sciences, Chinese Academy of Sciences, 320 Yue-yang Road, Shanghai 200031, People's Republic of China

\begin{abstract}
Second messenger signalling through cyclic AMP (cAMP) plays an important role in the response of the endometrium to prostaglandin ( $P G) E_{2}$ during early pregnancy. Arachidonic acid, which is a by-product of the luteolytic cascade in ruminants, is a potential paracrine signal from the epithelium to the stroma. We investigated the effects of arachidonic acid on the response of the stroma to $\mathrm{PGE}_{2}$. cAMP was measured in bovine endometrial stromal cells treated with agents known to activate or inhibit adenylyl cyclase, protein kinase $\mathrm{C}$ (PKC) or phosphodiesterase (PDE). $\mathrm{PGE}_{2}$ increased the intracellular cAMP concentration within $10 \mathrm{~min}$, and this effect was attenuated by arachidonic acid and the PKC activator, 4 $\beta$-phorbol myristate acetate (PMA). The inhibitory effect of arachidonic acid on $\mathrm{PGE}_{2}$-induced CAMP accumulation was prevented by the PKC inhibitor, RO318425, and was absent in cells in which PKC had been downregulated by exposure to PMA for $24 \mathrm{~h}$. The effect of arachidonic acid was also prevented by the PDE inhibitor, 3-isobutyl-1-methylxanthine. Arachidonic acid was shown by immunoblotting to prevent induction of cyclooxygenase-2 by $\mathrm{PGE}_{2}$, forskolin or dibutyryl cAMP. The results indicate that arachidonic acid activates PDE through a mechanism involving PKC, counteracting a rise in intracellular CAMP in response to $\mathrm{PGE}_{2}$. The data suggest that arachidonic acid antagonizes $\mathrm{PGE}_{2}$ signalling through $\mathrm{CAMP}$ in the bovine endometrium, possibly acting to ensure a rapid return to oestrus in the case of failure of the maternal recognition of pregnancy.

Reproduction (2007) 133 1017-1026
\end{abstract}

\section{Introduction}

Intracellular signalling through adenylyl cyclase and $3^{\prime}, 5^{\prime}$-cyclic AMP (cAMP) plays an important role in the preparation of the uterus for implantation. Compounds activating adenylyl cyclase in the endometrium include prostaglandin $(\mathrm{PG}) \mathrm{E}_{2}$, relaxin, activin, luteinizing hormone and corticotrophin-releasing hormone, all of which have been implicated in changes in endometrial function during early pregnancy (Tseng et al. 1992, Tang \& Gurpide 1993, Frank et al. 1994, Ferrari et al. 1995). Administration of dibutyryl cAMP to the uterine lumen in mice has been known for three decades to induce a decidual response and implantation (Webb 1977). Recently, it has been proposed that cAMP acts to support the action of progesterone, through synergy between the protein kinase A substrate, CREB and the progesterone receptor (Gellerson \& Brosens 2003).
The role of $\mathrm{PGE}_{2}$ in activating adenylyl cyclase at implantation has been particularly well defined in species with endometrial decidualization. In mouse, rat, rabbit and man, $\mathrm{PGE}_{2}$ is involved in endometrial angiogenesis (Jabbour \& Sales 2004), vasodilatation and vascular permeability (Kennedy 1983), stromal cell prolactin expression (Frank et al. 1994) and decidualization. These processes involve signalling through the $\mathrm{PGE}_{2}$ receptors EP2 and EP4, which are linked to adenylyl cyclase (Fujino et al. 2005) and are expressed by endometrial epithelial and stromal cells.

Although they are less well understood, $\mathrm{PGE}_{2}$ has similar effects in species without decidualization and in which implantation is superficial, such as ruminants. In the bovine uterus, epithelial and stromal cells express EP2 (but not EP4) receptors (Arosh et al. 2003); both cell types synthesize $\mathrm{PGE}_{2}$ (Fortier et al. 1988, Asselin et al. 1996), and PGE synthase concentrations increase with 
time after ovulation (Arosh et al. 2002). The blastocyst also secretes $\mathrm{PGE}_{2}$ in cattle (Wilson et al. 1992) and sheep (Marcus 1981, Hyland et al. 1982), and $\mathrm{PGE}_{2}$ is luteotrophic on administration to the uterine lumen (Magness et al. 1981). As a result, $\mathrm{PGE}_{2}$ has been suggested to function as a maternal recognition of pregnancy signal in these species. Thus, although all aspects of the involvement of $\mathrm{PGE}_{2}$ and cAMP in early pregnancy have not been demonstrated in all species, they are clearly involved whether or not the endometrium decidualizes.

Genes transcribed in response to cAMP in the endometrial stroma have principally been studied in the context of decidualization (Popovici et al. 2000). Among these are genes coding for a variety of transcription factors, growth factors and compounds involved in angiogenesis, and the decidualization marker prolactin (Christian et al. 2002, Gellerson \& Brosens 2003, Yoshino et al. 2003). They also include cyclooxygenase-2 (COX-2; Zhou et al. 1999, Schroer et al. 2002, Wu \& Wiltbank 2002), which plays an essential role in the establishment of pregnancy (Reese etal.2001) by converting arachidonic acid into prostanoids required for implantation (Lim et al. 1999). As COX-2 is induced by CAMP and produces the substrate for PGE synthase, and as $\mathrm{PGE}_{2}$ activates adenylyl cyclase, a positive feedback loop has been proposed whereby $\mathrm{PGE}_{2}$ induces its own synthesis (Sales et al. 2001, Arosh et al. 2004).

Intracellular concentrations of cAMP are determined not only by its synthesis, but also by its catabolism to $5^{\prime}$ AMP, which is catalysed by a member of the phosphodiesterase (PDE) family specific for CAMP (CAMP-PDE). CAMP-PDE is activated by phosphorylation, notably by protein kinase C (PKC; Tetsuka et al. 1995, Cai \& Lee 1996, Geoffroy et al. 1999, Bian et al. 2000). Compounds activating PKC might, therefore, be expected to reduce intracellular levels of CAMP, and so may oppose the action of $\mathrm{PGE}_{2}$ and hinder the establishment of pregnancy.

Arachidonic acid and other polyunsaturated fatty acids are PKC activators (Khan et al. 1995), which may lead to activation of cAMP-PDE. Arachidonic acid is produced in the endometrium at luteolysis through cytosolic phospholipase $A_{2}$ (Lee \& Silvia 1994, Burns et al. 2000) and in response to activation of phospholipase C following oxytocin receptor (OTR) occupancy (Flint et al. 1986), and has been proposed to act as a paracrine messenger between the endometrial epithelium and stroma at luteolysis (Sheldrick et al. 2006), as in other reproductive tissues (Cooke et al. 1991). Both OTR concentrations and PKC activity were higher in the non-pregnant horns of unilaterally pregnant ewes on day 16 after oestrus than they were in the pregnant horns of the same sheep (Abayasekara et al. 1995), which is consistent with oxytocin-induced production of PKC activators such as diacylglycerol or arachidonic acid. Control of arachidonic acid release from cells through endocrine or immune stimulation is consistent with paracrine or autocrine functions of fatty acids in other tissues (Zheng et al. 1999, Ronco et al. 2002).

In addition to $\mathrm{PGE}_{2}, \mathrm{COX}-2$ also provides the substrate for $\mathrm{PGF}_{2 \alpha}$ production, the ratio $\mathrm{PGE}_{2}: \mathrm{PGF}_{2 \alpha}$ produced being determined by the relative activities of PGE and PGF synthases. Through $\mathrm{PGF}_{2 \alpha}$ (FP) receptor activation of phospholipase C, $\mathrm{PGF}_{2 \alpha}$ also induces PKC (Abayasekara et al. 1993), and therefore, metabolites of arachidonic acid may also affect cAMP-PDE activity.

The experiments described here were designed to determine whether arachidonic acid interferes with cAMP signalling in bovine endometrial stromal cells, by measuring CAMP in cells in culture and using COX-2 levels as an indicator of the cellular response to cAMP signalling.

\section{Materials and Methods}

\section{Materials}

Unless otherwise stated, all compounds were obtained from Sigma or Calbiochem (Nottingham, UK). Arachidonic acid was stored under $\mathrm{N}_{2}$ at $-20{ }^{\circ} \mathrm{C}$ in darkness. Arachidonic acid, $\mathrm{PGE}_{2}$ and 3-isobutyl-1-methylxanthine (IBMX) were added to culture media in ethanol; $4 \beta$-phorbol myristate acetate (PMA) and RO318425 were added in dimethylsulphoxide. Control cultures contained the vehicle as appropriate.

\section{Cell culture}

Bovine uterine stromal (BST) cells isolated from one uterine horn of a non-pregnant cyclic cow on day 16 post-oestrus (Flint et al. 2002) were maintained in Dulbecco's modified Eagles medium (DMEM; Sigma) with 1\% antibioticantimycotic (ABAM; Sigma) and 10\% foetal bovine serum at $37{ }^{\circ} \mathrm{C}, 95 \%$ humidity and $5 \% \mathrm{CO}_{2}$. They were passaged at intervals of 3-4 days when about $80 \%$ confluent. The stromal (as opposed to epithelial) phenotype of the cells was confirmed by their prostanoid secretion pattern $\left(\mathrm{PGE}_{2}>\right.$ $\mathrm{PGF}_{2 a ;}$ Asselin et al. 1996). For experimental treatments, cells were plated into multiwell plates $48-72 \mathrm{~h}$ before use. The medium was changed to DMEM containing $10 \%$ dextran-coated charcoal-stripped foetal bovine serum and $1 \%$ ABAM at the time of addition of test compounds. For intracellular cAMP measurements, BST cells were seeded into six-well plates at a density of $10^{6}$ cells/well; for immunoblotting cells were plated in 24-well plates at a density of $2-4 \times 10^{5}$ cells/well.

\section{Immunoblotting}

Lysates (10 $\mu \mathrm{g}$ protein) were subjected to electrophoresis using $10 \%$ acrylamide gels (5\% stacking gels) before electroblotting onto Optitran BA-s 83 membrane (Schleicher and Schuell, Anderman and Company, Kingstonupon-Thames, UK) in $25 \mathrm{mmol} / \mathrm{l}$ Tris (pH 8.3) containing $148 \mathrm{mmol} / \mathrm{I}$ glycine and $20 \%(\mathrm{v} / \mathrm{v})$ methanol. For detection 
of COX-2, membranes were probed with COX-2 antibody (C-20; SC 1745, Santa Cruz, obtained through Autogen Bioclear, Calne, UK; 1:250 dilution in phosphate-buffered saline containing 1\% w/v Marvel milk powder and 0.5\% $\mathrm{v} / \mathrm{v}$ Tween 20). The second antibody was donkey anti-goat IgG-horseradish peroxidase (SC 2020; Santa Cruz; 1:11 000 dilution in phosphate-buffered saline containing $3 \% \mathrm{w} / \mathrm{v}$ Marvel, $0.5 \% \mathrm{v} / \mathrm{v}$ Tween 20 ), and visualization was by ECL (Amersham) using Kodak BioMax Light film. Colour Markers (29-205 kD; Sigma) were used to identify molecular weights of proteins, and band intensities were quantified using Kodak 1D digital image analysis software.

\section{$3^{\prime}, 5^{\prime}-c A M P$ assay}

After incubation with different treatments, the medium was removed and the cells were treated with $0.1 \mathrm{mmol} / \mathrm{l}$ $\mathrm{HCl}$ to inhibit PDE activity and lysed with $0.1 \% \mathrm{v} / \mathrm{v}$ Triton X-100 for $10 \mathrm{~min}$. The cAMP released was measured using either cAMP (low $\mathrm{pH}$ ) immunoassay kits or the Parameter cAMP assay system (both from R\&D Systems, Abingdon, UK) according to manufacturer's guidelines. Protein contents of lysates were measured to confirm that the wells contained equal numbers of cells; since this was consistently the case, cAMP concentrations were expressed as pmol cAMP/well.

\section{Protein assay}

Protein concentrations were measured in cell lysates by the BCA method (Perbio, Cramlingham, UK).

\section{Experimental design and analysis}

Experiments involved treatments carried out with at least three replicates (for cAMP measurement) or four replicates (for immunoblotting). All experiments were performed at least twice. To account for differences in band intensity between immunoblots, all blots included two control samples and all experimental treatments were related to the control bands. Statistical analysis of treatment effects was performed by analysis of variance using Genstat, with treatment and experiment identifier as factors. Where significant $(P<0.05)$ effects were detected, individual means were tested by Student's $t$-test. Values are given as means \pm s.E.M., and in the figures, bars with different letters are significantly different.

\section{Results}

\section{$P G E_{2}$ increases cAMP concentration in BST cells}

To confirm that $\mathrm{PGE}_{2}$ activated adenylyl cyclase in BST cells, cAMP was measured in cells exposed to $\mathrm{PGE}_{2}$ for varying times. As expected from the expression of EP2 receptors by bovine endometrium (Arosh et al. 2003), $\mathrm{PGE}_{2}$ raised intracellular cAMP levels. In separate experiments, a 2.1-fold increase in CAMP was observed within $10 \mathrm{~min}$ of addition of $\mathrm{PGE}_{2}$ and a threefold increase within $20 \mathrm{~min}$ (Fig. 1). None of the treatments affected cell protein concentration.

\section{Inhibition by arachidonic acid of $P G E_{2}$-induced increase in CAMP concentration}

To determine whether arachidonic acid affected $\mathrm{PGE}_{2}-$ induced cAMP accumulation, cells were treated with both $\mathrm{PGE}_{2}$ and arachidonic acid. As shown in Fig. $2 \mathrm{a}$, the increase in CAMP observed when cells were treated with $\mathrm{PGE}_{2}$ was reduced by addition of arachidonic acid. Separate dose-response experiments showed that the concentration of arachidonic acid required to cause this effect was in the range of $\mu \mathrm{mol} / \mathrm{l}$ (Fig. 2b).

\section{Inhibition of $P G E_{2}$-induced $C A M P$ accumulation by arachidonic acid is dependent on the $P K C$ signalling pathway and requires activation of PDE}

One possible mechanism by which arachidonic acid may block cAMP production is through PKC (Khan et al. 1995). This was confirmed using the PKC activator, $4 \beta-$ PMA, which mimicked the effect of arachidonic acid (Fig. 3a). Furthermore, the inhibitory effect of arachidonic acid on the $\mathrm{PGE}_{2}$-induced rise in CAMP level was blocked in cells cultured with the PKC inhibitor,

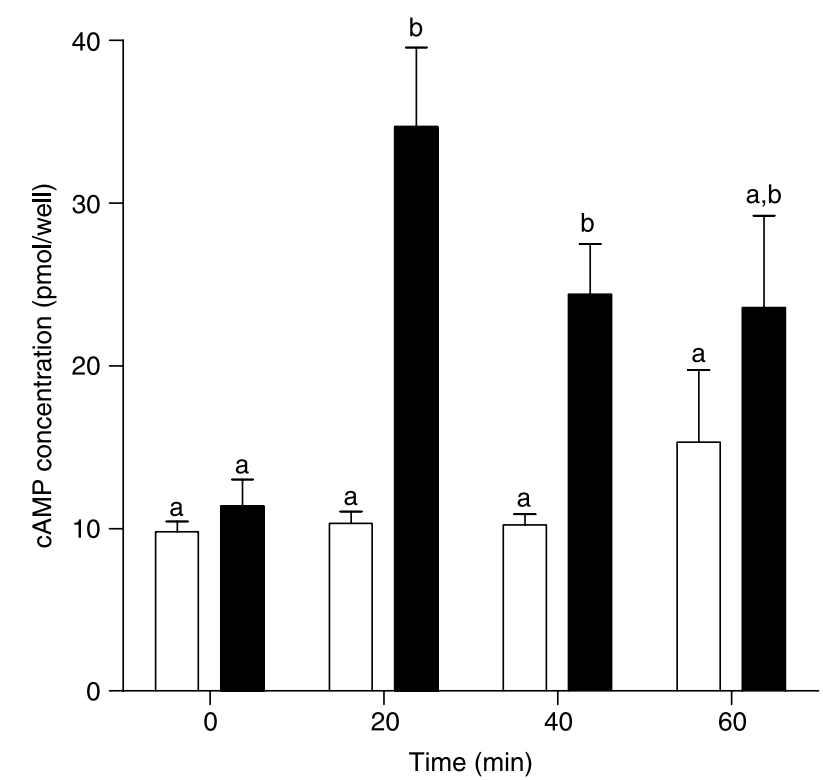

Figure $1 \mathrm{PGE}_{2}$ increased cyclic $\mathrm{AMP}$ concentration in bovine endometrial stromal (BST) cells. Cells were treated with $\mathrm{PGE}_{2}$ $(3 \mu \mathrm{mol} / \mathrm{l})$ for various lengths of time before extraction for cyclic AMP assay. Open bars, control; closed bars, $\mathrm{PGE}_{2}$. The cyclic AMP concentration was raised at 20 and $40 \mathrm{~min}(P<0.05)$, but the difference at $60 \mathrm{~min}$ was not statistically significant. In separate experiments, cyclic AMP levels were raised within 10 min of addition of $\mathrm{PGE}_{2}$. In this and other figures, different superscript letters indicate significant effects. 

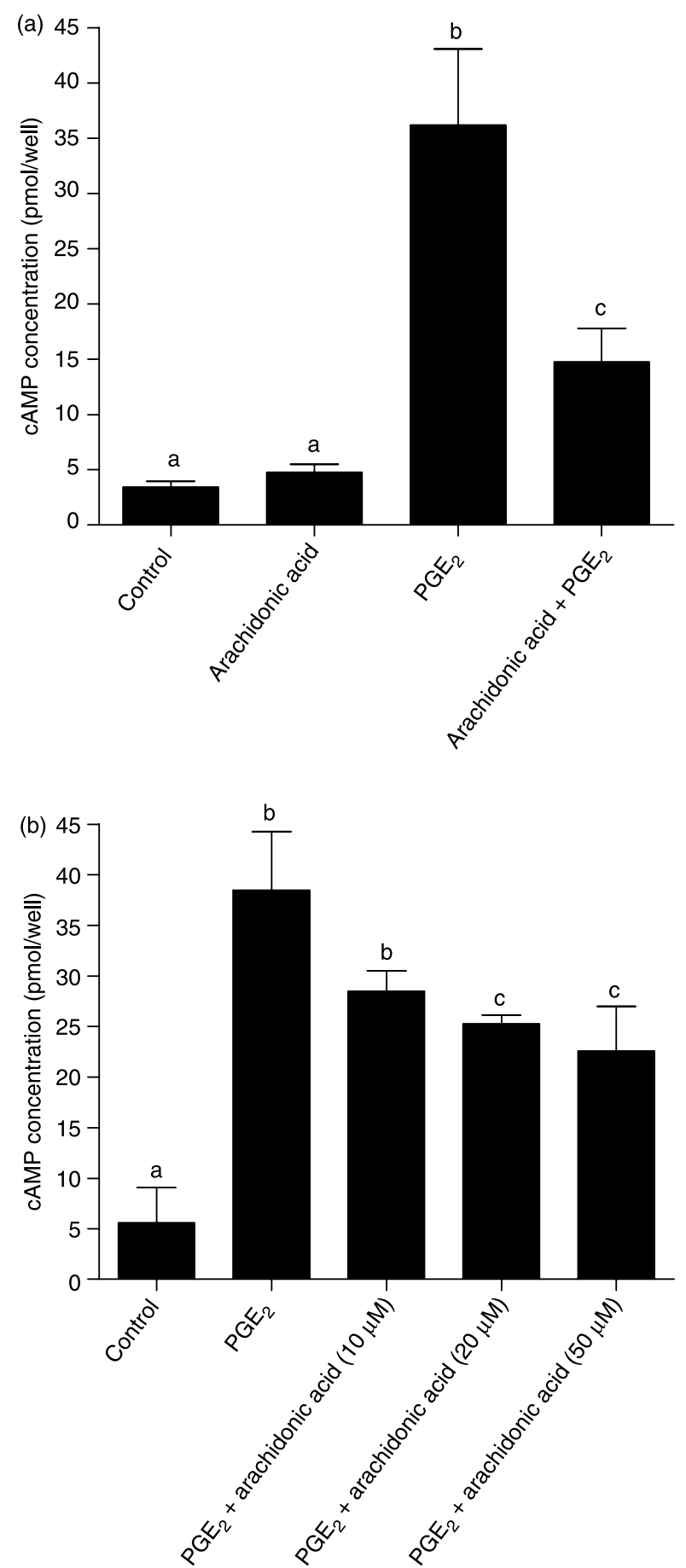

Figure 2 The effect of $\mathrm{PGE}_{2}$ on intracellular cyclic AMP level was antagonized by arachidonic acid. (a) The intracellular concentration of cyclic AMP was increased by $3 \mu \mathrm{mol} / \mathrm{l} \mathrm{PGE} \mathrm{PG}_{2}(P<0.001)$, but not by $50 \mu \mathrm{mol} / \mathrm{l}$ arachidonic acid alone. Arachidonic acid $(50 \mu \mathrm{mol} / \mathrm{l})$ reduced the level of cyclic AMP in cells treated with $\mathrm{PGE}_{2}(3 \mu \mathrm{mol} / \mathrm{l})$ for $20 \mathrm{~min}(P<0.02)$. (b) Dose-response experiments (carried out for $20 \mathrm{~min})$ showed that arachidonic acid was effective $(P<0.05)$ in the range of $\mu \mathrm{mol} / \mathrm{l}$.
RO318425 (Fig. 3b), and also by prolonged exposure of cells to 4 $\beta-P M A$, which downregulates PKC (Akita et al. 1990, Kiley et al. 1990; Fig. 3c).

In view of the evidence from other cell types that PKC phosphorylates and thereby activates PDE isoforms responsible for metabolizing cAMP (Tetsuka et al. 1995, Cai \& Lee 1996, Geoffroy et al. 1999, Bian et al. 2000), cells were cultured with the PDE inhibitor, IBMX. In the presence of $0.1 \mathrm{mmol} / \mathrm{I} \mathrm{IBMX}$, the inhibitory effect of arachidonic acid on $\mathrm{PGE}_{2}$-induced CAMP accumulation was blocked (Fig. 3d). Identical effects were observed with $1 \mathrm{mmol} / \mathrm{I} \mathrm{IBMX}$ (data not shown).

\section{Effect of arachidonic acid on CAMP-induced COX-2 expression}

To confirm that the effect of arachidonic acid on PDE was reflected in a cellular response to CAMP, COX-2 was measured by immunoblotting in cells treated with $\mathrm{PGE}_{2}$ or dibutyryl CAMP with and without arachidonic acid. As anticipated (see Introduction), dibutyryl cAMP added alone increased COX-2 protein levels (Fig. $4 \mathrm{a}$ ), and $\mathrm{PGE}_{2}$ caused the same response (Fig. 4c). As expected on the basis of the activation of PDE, the increase in COX-2 level due to dibutyryl cAMP or $\mathrm{PGE}_{2}$ was blocked by arachidonic acid. A similar observation was made with forskolin $(1 \mathrm{mmol} / \mathrm{l}$ for $6 \mathrm{~h})$, which increased COX-2 levels by $46 \%$ when added alone and by $7 \%$ when added with arachidonic acid (data not shown).

\section{Discussion}

Arachidonic acid antagonized the stimulatory effect of $\mathrm{PGE}_{2}$ on cAMP levels in endometrial stromal cells. The effect of arachidonic acid required activation of PKC, since it was mimicked by the PKC activator, $4 \beta-P M A$, and blocked by the PKC inhibitor, RO318425, and downregulation of PKC. The effect appeared to be due to activation of cAMP-dependent PDE, since it was prevented by the PDE inhibitor, IBMX (although it should be noted that IBMX is not specific and other effects cannot be ruled out).

Activation of cAMP-dependent PDE by PKC is well known in other cell types, from studies of whole tissues (hamster heart, Lee et al. 1994; rat renal medullary collecting tubule, Tetsuka et al. 1995), intact cells (luteinizing human granulosa cells, Michael \& Webley 1991; rat cardiac myocytes, Bian et al. 2000) and subcellular fractions (liver Golgi-endosomal fraction; Geoffroy et al. 1999). It occurs through a series of phosphorylation steps involving mitogen-activated protein kinase and PKA (Houslay \& Adams 2003). There are many isoforms of PDE, as well as the kinases involved in this process, and it is not known which isoforms are present, or functional, in the bovine endometrium. 
(a)

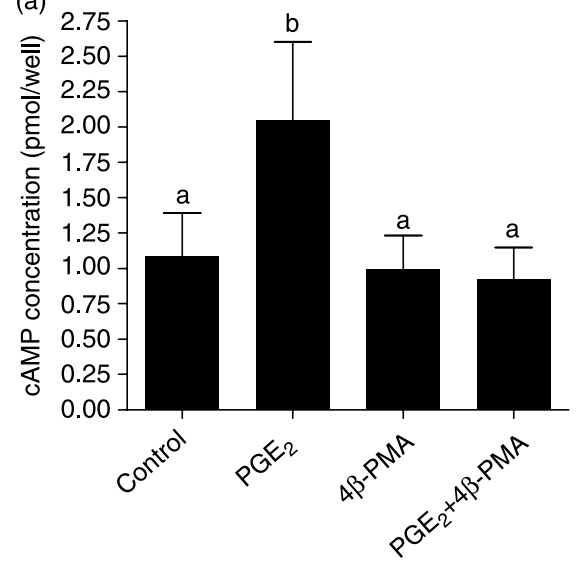

(b)

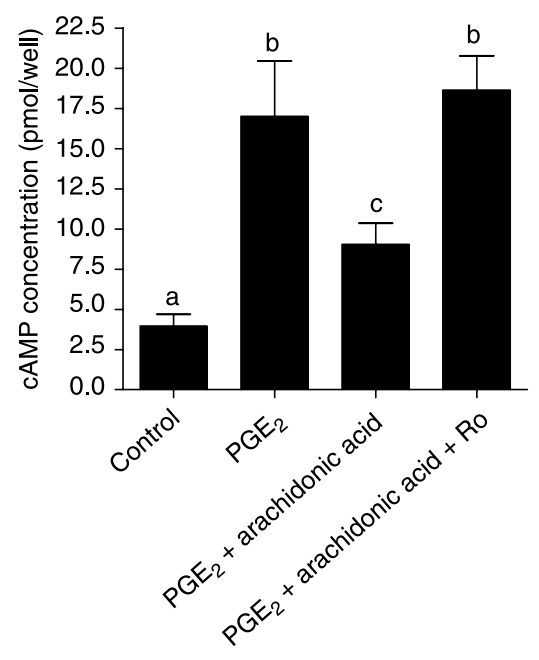

(d)

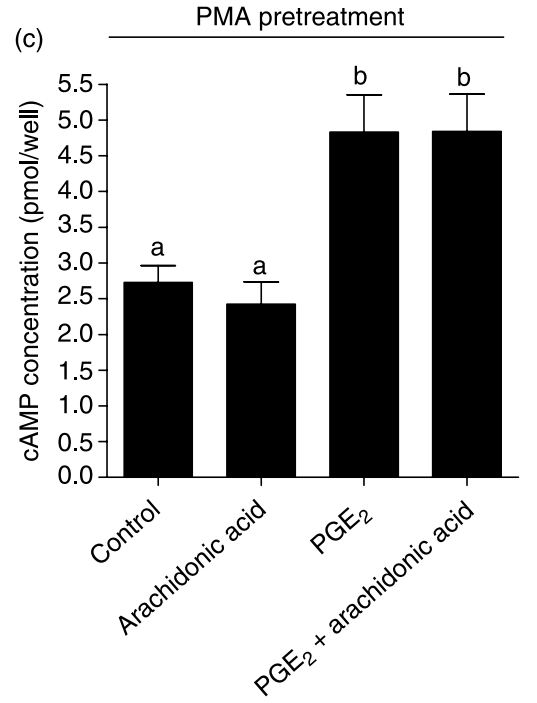

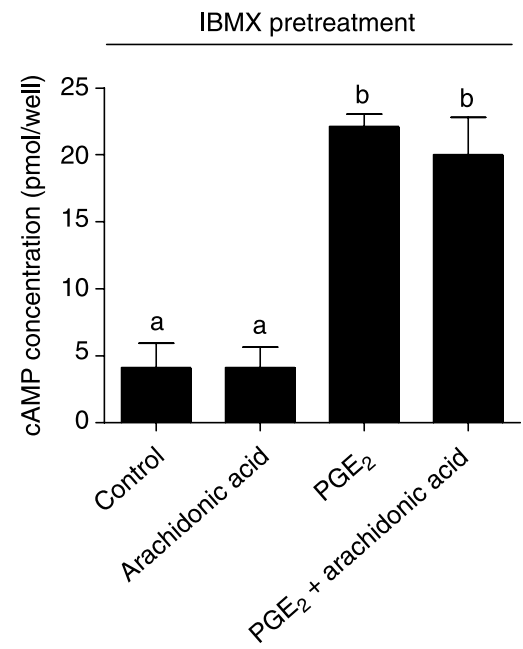

Figure 3 The inhibitory effect of arachidonic acid on $\mathrm{PGE}_{2}$-induced cyclic AMP depends on protein kinase $\mathrm{C}$ (PKC) and phosphodiesterase. In each case, cultures were terminated 20 min after adding arachidonic acid or $\mathrm{PGE}_{2}$. (a) PMA ( $2 \mu \mathrm{mol} / \mathrm{l} ; \mathrm{PMA}$ ) added $10 \mathrm{~min}$ before $\mathrm{PGE}_{2}$ prevented the rise in cyclic AMP concentration in response to $3 \mu \mathrm{mol} / / \mathrm{PGE}_{2}$ $(P<0.01)$. (b) The PKC inhibitor, RO318425 $(500 \mathrm{nmol} / \mathrm{l})$, added $10 \mathrm{~min}$ before arachidonic acid $(50 \mu \mathrm{mol} / \mathrm{l})$ and $\mathrm{PGE}_{2}(3 \mu \mathrm{mol} / \mathrm{l})$ prevented the antagonistic effect of arachidonic acid $(P<0.05)$. (c) The inhibitory effect of arachidonic acid was absent in cells pretreated with PMA for $24 \mathrm{~h}$ to downregulate PKC (compare with Fig. 2a). $\mathrm{PGE}_{2}$ alone versus $\mathrm{PGE}_{2}$ and arachidonic acid, $P>0.05$. (d) The inhibitory effect of arachidonic acid on $\mathrm{PGE}_{2}$-induced cyclic AMP depended upon phosphodiesterase. Cells pre-treated for 30 min with the phosphodiesterase inhibitor IBMX $(0.1 \mathrm{mmol} / \mathrm{l})$ were subsequently treated with $\mathrm{PGE}_{2}$ and/or arachidonic acid. Under these conditions, the inhibitory effect of arachidonic acid on $\mathrm{PGE}_{2}$-induced cyclic AMP level was absent (compare with Fig. 2a). $\mathrm{PGE}_{2}$ alone versus $\mathrm{PGE}_{2}$ and arachidonic acid, $P>0.05$.
To confirm that the inhibitory effect of arachidonic acid on the cAMP pathway was reflected at the cell protein level, we measured concentrations of COX-2 in cells treated with the cell membrane-permeable cAMP analogue, dibutyryl cAMP. COX-2 is induced in the uterus by cAMP (Arosh et al. 2004) and is therefore an appropriate marker for effects exerted through this second messenger pathway. In these experiments, arachidonic acid blocked or reduced the effect of dibutyryl cAMP. This is consistent with the activation of PDE since dibutyryl cAMP is sequentially hydrolysed, once inside the cell, to monobutyryl cAMP and cAMP. The cAMP generated in this way then activates PKA. Therefore, increased CAMP-PDE activity would be expected to prevent PKA activation through removal of cAMP derived from dibutyryl cAMP and, hence, to block COX-2 accumulation. Identical effects were observed with $\mathrm{PGE}_{2}$ (Fig. 4c) and forskolin, both of which activate adenylyl cyclase.
It was not our aim to identify the mechanisms by which COX-2 levels were affected, but to use COX-2 as an indicator of a cellular response, and therefore, we cannot differentiate between increased gene expression and reduced turnover of COX-2 transcripts or protein. However, COX-2 is under the transcriptional control of CREB through a well-recognized cAMP response element in the gene promoter (Zhou et al. 1999, Wu \& Wiltbank 2002, Schroer et al. 2002). Therefore, it is probable that the increased COX-2 level in response to dibutyryl cAMP reflected increased transcription.

It is unlikely that the effect observed here is specific to arachidonic acid, as PKC is activated by a wide range of polyunsaturated fatty acids (Shinomura et al. 1991, Khan et al. 1995). In practice, the fatty acids involved will probably reflect the composition of the phospholipids from which they are derived. As shown by Elmes et al. (2004), arachidonic acid is present at a higher concentration than any other polyunsaturated fatty acid (PUFA) 
(a)

$\begin{array}{lllllllll}1 & 2 & 3 a & 3 b & 3 c & 4 a & 4 b & 4 c\end{array}$

(b)

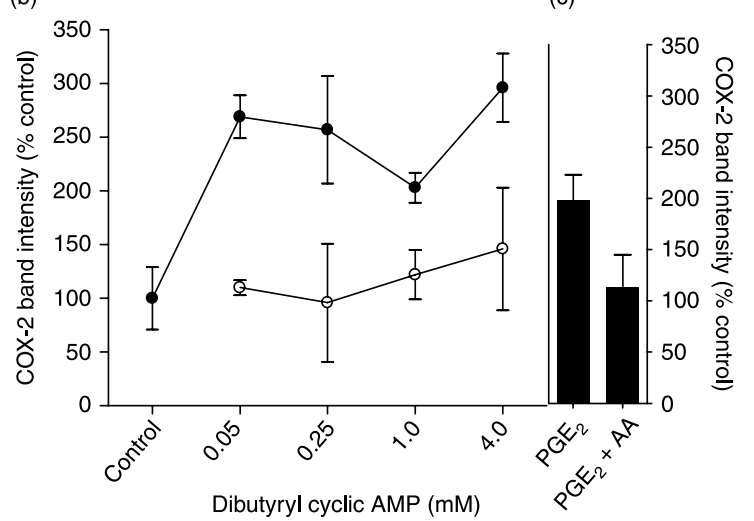

Figure 4 COX-2 protein levels determined by immunoblotting in bovine endometrial stromal cells. (a) Representative immunoblot showing: 1 , untreated cells; 2 , cells treated with arachidonic acid (50 $\mu \mathrm{mol} / \mathrm{l})$; 3a-c, separate cultures treated with dibutyryl cyclic AMP $(0.25 \mu \mathrm{mol} / \mathrm{l})$; $4 \mathrm{a}-\mathrm{C}$, separate cultures treated with dibutyryl cyclic AMP $(0.25 \mu \mathrm{mol} / \mathrm{l})$ and arachidonic acid $(50 \mu \mathrm{mol} / \mathrm{l})$. All treatments were for $6 \mathrm{~h}$. All bands are from adjacent wells on a single gel. (b) Effects of dibutyryl cyclic AMP on COX-2 levels. BST cells were cultured for $6 \mathrm{~h}$ with dibutyryl cyclic $\operatorname{AMP}(0.05,0.25,1.0$ and $4.0 \mathrm{mmol} / \mathrm{l})$ with (open symbols) or without (closed symbols) arachidonic acid $(50 \mu \mathrm{mol} / \mathrm{l})$. Dibutyryl cyclic AMP increased COX-2 levels in BST cells (ANOVA; $P<0.001$ ). The effect of dibutyryl cyclic AMP was antagonized by arachidonic acid $(P<0.001)$ at all dibutyryl cyclic AMP concentrations tested. (c) Arachidonic acid $(50 \mu \mathrm{mol} / \mathrm{l})$ antagonized the effect of $\mathrm{PGE}_{2}(3 \mu \mathrm{mol} / \mathrm{l})$ on COX-2 levels in cells cultured for $6 \mathrm{~h}$. COX-2 level was increased by $\mathrm{PGE}_{2}$ in the absence of arachidonic acid $(P<0.05)$.

in phosphatidylcholine and phosphatidylethanolamine in the endometrium in ewes, and it is likely that the same applies in cattle. All the other six unsaturated fatty acids present are effective activators of PKC.

Endogenous synthesis of $\mathrm{PGE}_{2}$ by the cells was unlikely to be a factor in the present investigation, as the culture media were changed immediately before test substances were added, hence removing prostanoids accumulated before the experimental period. Rates of production of $\mathrm{PGE}_{2}$ by BST cells in the presence of $50 \mu \mathrm{mol} / \mathrm{l}$ arachidonic acid were $\sim 20 \mathrm{pmol} / \mathrm{mg}$ protein per min (ELR Sheldrick unpublished observations), which with $0.15 \mathrm{mg}$ cell protein per well would be expected to produce a concentration of $6 \mathrm{nmol} / \mathrm{l}$ in $5 \mathrm{ml}$ medium after $20 \mathrm{~min}$ incubation. This is $\sim 0.2 \%$ of the concentration of $\mathrm{PGE}_{2}$ used to activate adenylyl cyclase $(3 \mu \mathrm{mol} / \mathrm{l})$, and would not be reached until the end of the 20 min incubation with test substances. Conversion of exogenous arachidonic acid to $\mathrm{PGE}_{2}$ clearly did not prevent the inhibitory effect of arachidonic acid, presumably because culture times after addition of test substances were short.

A similar argument suggests that the effect of arachidonic acid was not likely to have resulted from the conversion to $\mathrm{PGF}_{2 \alpha}$. The rate of synthesis of $\mathrm{PGF}_{2 \alpha}$ in the presence of arachidonic acid was $\sim 1 / 100$ that of $\mathrm{PGE}_{2}$, giving a concentration of $0.06 \mathrm{nmol} / \mathrm{l}$ after $20 \mathrm{~min}$. Although the stromal cells used here express the FP receptor (ELR Sheldrick unpublished observations), this concentration of $\mathrm{PGF}_{2 \alpha}$ is $0.006 \%$ of that required to activate phospholipase $\mathrm{C}$ in other cell types (Abayasekara et al. 1993).

In addition to their effects on PDE, arachidonic acid and other polyunsaturated fatty acids have both activatory and inhibitory actions on adenylyl cyclase, depending upon the adenylyl cyclase isoform and G proteins expressed in target cells. For instance in cells expressing the $G$ protein $G_{z}\left(a G_{i}\right.$ isoform), such as neuronal cells and platelets, arachidonic acid inactivates $\mathrm{G}_{\mathrm{z}}$ leading to adenylyl cyclase activation (Glick et al. 1996). In contrast, in brain cell membrane preparations, arachidonic acid inhibits adenylyl cyclase by a direct interaction with the catalytic subunit (Nakamura et al. 2001). Arachidonic acid may also affect adenylyl cyclase activity through phosphorylation via PKC; in cells expressing type $\mathrm{V}$ adenylyl cyclase, phosphorylation by PKC is activatory (Kawabe et al. 1994), whereas in cells expressing type $\mathrm{VI}$ adenylyl cyclase, it is inhibitory (Lin et al. 2002). Therefore, the possibility exists that PUFA cause other actions through modulation of the CAMP/ protein kinase pathway. Effects such as these did not appear to be important in the present experiments, where there was no change in basal cAMP concentration with arachidonic acid alone. However, the cells were exposed to arachidonic acid for a short time $(20 \mathrm{~min})$, and it is not possible to rule out an effect with a slower onset.

The concentration of arachidonic acid used in these experiments $(50 \mu \mathrm{mol} / \mathrm{l})$ was consistent with the concentration required to activate purified PKC $(20-50 \mu \mathrm{mol} / /$; Shinomura et al. 1991). It is probably within the physiological range in the cells in terms of the intracellular level reached during the culture period. The concentration of free arachidonic acid in bovine stroma has not been reported, but can be inferred from the $K_{m}$ of enzymes for which it is a substrate (for instance, COX-2, $\sim 5 \mu \mathrm{mol} / \mathrm{l}$; Smith et al. 1996) and the concentration of arachidonic acid-containing phospholipids $(\sim 800 \mathrm{nmol} / \mathrm{g}$, i.e. $800 \mu \mathrm{mol} / \mathrm{l}$ on the basis of $1 \mathrm{ml} / \mathrm{g}$; Elmes et al. 2004). On the other hand, the intracellular concentration of arachidonic acid is unlikely to have reached $50 \mu \mathrm{mol} / \mathrm{l}$ in the short time for which the cells were exposed to it $(20 \mathrm{~min})$, since arachidonic acid was added to medium containing charcoal-stripped serum, which would not prevent it gaining access to the cells, but might be expected to bind arachidonic acid avidly, reducing its availability.

In the endometrial stromal cells used here, arachidonic acid antagonized the stimulatory effect of dibutyryl cAMP or $\mathrm{PGE}_{2}$ at the level of cell protein, as shown by measuring COX-2 levels (Fig. 4). This is 


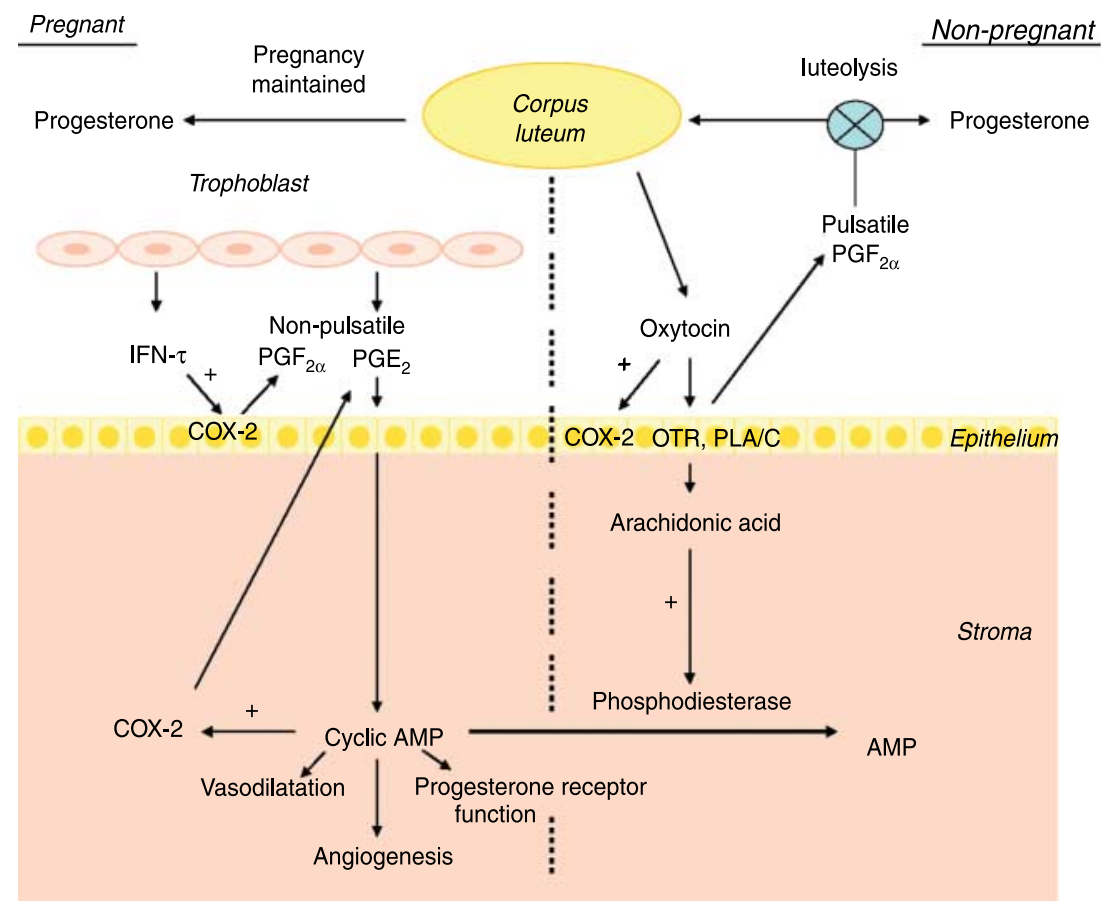

Figure 5 Proposed interactions between luteotrophic and luteolytic pathways in the choice between pregnancy and a return to cyclicity in polyoestrous ruminants, in which interferon- $\tau$ is the maternal recognition of pregnancy signal and there is no decidualization. Luteotrophic signals released by the pre-attachment conceptus include $\mathrm{PGE}_{2}$ (secreted from day 10 post-conception) and interferon- $\tau$ (secreted from day 15). PGE $\mathrm{E}_{2}$ acts through EP2 receptors to activate adenylyl cyclase leading to raised levels of cyclic AMP and subsequently angiogenesis, vasodilatation, support for the progesterone receptor and induction of COX-2. The effect on COX-2, in turn, leads to further $\mathrm{PGE}_{2}$ production through PGE synthase in the stroma. Interferon- $\tau$ (IFN- $\tau$ ) prevents expression of the oxytocin receptor (OTR) in the epithelium and induces COX-2 in the epithelium. Absence of OTR prevents episodic $\mathrm{PGF}_{2 \alpha}$ secretion, and chronically elevated non-pulsatile $\mathrm{PGF}_{2 \alpha}$ and $\mathrm{PGE}_{2}$ are antiluteolytic. In the absence of IFN- $\tau$, this pathway is opposed by luteolytic mechanisms involving oxytocin secretion by the corpus luteum. Oxytocin acts through the oxytocin receptor expressed initially by epithelial cells to stimulate release of arachidonic acid through phospholipases $A$ and $C(P L A / C)$ and expression of COX-2. Arachidonic acid is converted to $\mathrm{PGF}_{2 \alpha}$ by the epithelium stimulating episodic secretion of oxytocin by the corpus luteum, leading to luteolysis. Arachidonic acid reduces cyclic AMP levels by activating a cyclic AMP-specific phosphodiesterase, thereby counteracting the effects of PGE $\mathrm{E}_{2}$ on the stroma.

consistent with the induction of PDE by arachidonic acid and confirms that the effect on cAMP level was reflected in protein synthesis. The results also show that arachidonic acid has both stimulatory and inhibitory effects on COX-2, since it increases COX-2 levels in bovine endometrial epithelial cells when added alone (Parent et al. 2003). These effects have different time courses, in that the action through PDE shown here is rapid (within $10 \mathrm{~min}$ ), while the rise in COX-2 demonstrated by Parent et al. (2003) peaks at $6 \mathrm{~h}$. The explanation for these apparently contradictory responses may lie in the promiscuity of the COX-2 promoter, which is sensitive to many transcription factors. Their reconciliation at a molecular level must await further understanding of the crosstalk between the second messenger pathways involved.

Events leading to PG production in bovine endometrial tissues are temporally and spatially separated. Beginning at about day 10 after conception, the conceptus secretes $\mathrm{PGE}_{2}$, which initiates a positive feedback loop in the stroma whereby cAMP production leads to COX-2 induction and further production of $\mathrm{PGE}_{2}$. After day 15, in the event that conceptus interferon- $\tau$ (IFN- $\tau)$ secretion is absent or insufficient, the OTR is expressed in the epithelium, leading to episodes of $\mathrm{PGF}_{2 \alpha}$ secretion, which result in luteolysis and a further chance to ovulate. Spatial separation arises because the epithelium expresses the OTR earlier than the stroma and is the principal source of $\mathrm{PGF}_{2 \alpha,}$ whereas the stroma does not express the OTR until oestrus, and produces principally $\mathrm{PGE}_{2}$ (Asselin et al. 1996, Robinson et al. 1999). Expression of COX-2 in the epithelium is increased both by oxytocin in the non-pregnant animal (Parent et al. 2003) and by IFN- $\tau$ in pregnancy (Emond et al. 2004). Interferons also activate phospholipase $A_{2}$ (Hannigan \& Williams 1991), which would be expected to increase the availability of arachidonic acid to COX-2. In both cases, these effects lead to increased secretion of $\mathrm{PGF}_{2 \alpha}$. In the non-pregnant animal, the secretion of $\mathrm{PGF}_{2 \alpha}$ is pulsatile, as a result of a positive feedback loop stimulating further luteal secretion of oxytocin (Flint \& Sheldrick 1982). In pregnancy, IFN- $\tau$ leads to increased secretion of PGF $_{2 \alpha}$ (Peterson et al. 1976, Payne \& Lamming 1994), but without pulses. Secretion of $\mathrm{PGF}_{2 \alpha}$ is required to be pulsatile in order to cause luteolysis, and as a result, oxytocin causes luteolysis but 
IFN- $\tau$ does not. Indeed, a prolonged and sustained rise in $\mathrm{PGF}_{2 \alpha}$ in response to IFN- $\tau$ may lead to luteal refractoriness through downregulation of PKC (Abayasekara et al. 1993), and hence act as an antiluteolysin.

The physiological significance of the inhibitory action of arachidonic acid on the adenylyl cyclase pathway presumably resides in inhibitory effects not only on COX-2 and the response to $\mathrm{PGE}_{2}$, but also on other compounds acting through cAMP. The effect of arachidonic acid on $\mathrm{PGE}_{2}$-induced CAMP accumulation observed here would be expected to prevent responses to agents elevating cAMP levels such as relaxin, activin, luteinizing hormone and corticotrophin-releasing hormone (Bartscha \& Ivell 2004, Tierney \& Giudice 2004). In this context, arachidonic acid may be viewed as a component of a complex of luteolytic signals maintaining the endometrium in a non-pregnant state characterized by a low level of cAMP, absence of decidualization, vasodilatation and endometrial angiogenesis, and lack of support for the progesterone receptor (Gellerson \& Brosens 2003). These interactions are summarized for ruminants in Fig. 5. The outcome of a reduction in endometrial CAMP level may therefore be to ensure blockade of signals associated with pregnancy, such as increased stromal COX-2 and $\mathrm{PGE}_{2}$ production, in the event IFN- $\tau$ production is low and pregnancy is likely to fail. This would impart the selection advantage of securing resumption of cyclicity and a further chance of conception at the earliest opportunity.

\section{Acknowledgements}

We thank the staff of the Division of Animal Physiology, School of Biosciences, University of Nottingham, particularly Pat Fisher for deriving the endometrial stromal cells, and Morag Hunter, George Mann and Bob Robinson for helpful discussions. This work was funded by the Biotechnology and Biological Sciences Research Council and the Wellcome Trust. The authors declare that there is no conflict of interest that would prejudice the impartiality of this scientific work.

\section{References}

Abayasekara DRE, Jones PM, Persaud SJ, Michael AE \& Flint APF 1993 Prostaglandin $\mathrm{F}_{2 \alpha}$ activates protein kinase $\mathrm{C}$ in human ovarian cells. Molecular and Cellular Endocrinology 91 51-57.

Abayasekara DRE, Sheldrick EL, Flick-Smith HC \& Flint APF 1995 Role of protein kinase $C$ in the inhibitory action of trophoblast interferons on expression of the oxytocin receptor in sheep endometrium. Endocrine 3 151-158.

Akita Y, Ohno S, Yajima Y \& Suzuki K 1990 Possible role of $\mathrm{Ca}^{2+}$. independent protein kinase $\mathrm{C}$ isozyme, $\mathrm{nPKC} \varepsilon$, in thyrotropinreleasing hormone-stimulated signal transduction: differential downregulation of $\mathrm{nPKC} \varepsilon$ in $\mathrm{GH}_{4} \mathrm{C}_{1}$ cells. Biochemical and Biophysical Research Communications 172 184-189.

Arosh JA, Parent J, Chapdelaine P, Sirois J \& Fortier MA 2002 Expression of cyclooxygenases 1 and 2 and prostaglandin E synthase in bovine endometrial tissue during the estrous cycle. Biology of Reproduction 67 161-169.
Arosh JA, Banu SK, Chapdelaine P, Emond V, Kim JJ, Maclaren LA \& Fortier MA 2003 Molecular cloning and characterization of bovine prostaglandin $\mathrm{E}_{2}$ receptors EP2 and EP4: expression and regulation in endometrium and myometrium during the estrous cycle and early pregnancy. Endocrinology 144 3076-3091.

Arosh JA, Banu SK, Kimmins S, Chapdelaine P, MacLaren LA \& Fortier MA 2004 Effect of interferon- $\tau$ on prostaglandin biosynthesis, transport, and signaling at the time of maternal recognition of pregnancy in cattle: evidence of polycrine actions of prostaglandin $\mathrm{E}_{2}$. Endocrinology 145 5280-5293.

Asselin E, Goff AK, Bergeron H \& Fortier MA 1996 Influence of sex steroids on the production of prostaglandin $\mathrm{F}_{2 \alpha}$ and $\mathrm{E}_{2}$ and response to oxytocin in cultured epithelial and stromal cells of the bovine endometrium. Biology of Reproduction 54 371-379.

Bartscha O \& Ivell R 2004 Relaxin and phosphodiesterases collaborate during decidualization. Annals of the New York Academy of Sciences 1030 479-492.

Bian J-S, Zhang W-M, Pei J-M \& Wong T-M 2000 The role of phosphodiesterase in mediating the effect of protein kinase $C$ on cyclic AMP accumulation upon $\kappa$-opioid receptor stimulation in the rat heart. Journal of Pharmacology and Experimental Therapeutics 292 1065-1070.

Burns PD, Graf GA, Hayes SH \& Silvia WJ 2000 Effect of oxytocin on expression of cytosolic phospholipase $A_{2}$ mRNA and protein in ovine endometrial tissue in vivo. Domestic Animal Endocrinology 19 237-246.

Cai JJ \& Lee H-C 1996 Protein kinase C isozyme-specific modulation of cyclic AMP-dependent phosphodiesterase in hypertrophic cardiomyopathic hamster hearts. Molecular Pharmacology 49 81-88.

Christian M, Zhang X, Schneider-Merck T, Unterman TG, Gellerson B, White JO \& Brosens JJ 2002 Cyclic AMP-induced forkhead transcription factor, FKHR, cooperates with CCAAT/enhancerbinding protein $\beta$ in differentiating human endometrial stromal cells. Journal of Biological Chemistry 277 20825-20832.

Cooke BA, Dirami L, Chaudry L, Choi MSK, Abayasekara DRE \& Phipp L 1991 Release of arachidonic acid and the effects of corticosteroids on steroidogenesis in rat testis Leydig cells. Journal of Steroid Biochemistry and Molecular Biology 40 465-471.

Elmes M, Tew P, Cheng Z, Kirkup SE, Abayasekara DRE, Calder PC, Hanson MA, Wathes DC \& Burdge GC 2004 The effect of dietary supplementation with linoleic acid to late gestation ewes on the fatty acid composition of maternal and fetal plasma and tissues and the synthetic capacity of the placenta for 2-series prostaglandins. Biochimica et Biophysica Acta 1686 139-147.

Emond V, MacLaren LA, Kimmins S, Arosh JA, Fortier MA \& Lambert RD 2004 Expression of cyclooxygenase-2 and granulocyte-macrophage colony-stimulating factor in the endometrial epithelium of the cow is up-regulated during early pregnancy and in response to intrauterine infusions of interferon- $\tau$. Biology of Reproduction 70 54-64.

Ferrari A, Petraglia F \& Gurpide E 1995 Corticotropin releasing factor decidualizes human endometrial stromal cells in vitro. Journal of Steroid Biochemistry and Molecular Biology 54 251-255.

Flint APF \& Sheldrick EL 1982 Ovarian secretion of oxytocin is stimulated by prostaglandin. Nature 297 587-588.

Flint APF, Leat WMF, Sheldrick EL \& Stewart HJ 1986 Stimulation of phosphoinositide hydrolysis by oxytocin and the mechanism by which oxytocin controls prostaglandin synthesis in the ovine endometrium. Biochemical Journal 237 797-805.

Flint APF, Sheldrick EL \& Fisher PA 2002 Ligand-independent activation of steroid receptors. Domestic Animal Endocrinology 23 $13-24$.

Fortier MA, Guilbault LA \& Grasso F 1988 Specific properties of epithelial and stromal cells from the endometrium of cows. Journal of Reproduction and Fertility 83 239-248.

Frank GR, Brar AK, Cedars MI \& Handwerger S 1994 Prostaglandin $E_{2}$ enhances human endometrial stromal cell differentiation. Endocrinology 134 258-263. 
Fujino H, Salvi S \& Regan JW 2005 Differential regulation of phosphorylation of the CAMP response element-binding protein after activation of $\mathrm{EP}_{2}$ and $\mathrm{EP}_{4}$ prostanoid receptors by prostaglandin $\mathrm{E}_{2}$. Molecular Pharmacology 68 251-259.

Gellerson B \& Brosens J 2003 Cyclic AMP and progesterone receptor cross-talk in human endometrium: a decidualizing affair. Journal of Endocrinology 178 357-372.

Geoffroy V, Fouque F, Nivet V, Clot J-P, Lugnier C, Desbuquois B \& Benelli C 1999 Activation of a cGMP-stimulated cAMP phosphodiesterase by protein kinase $\mathrm{C}$ in a liver Golgi-endosomal fraction. European Journal of Biochemistry 259 892-900.

Glick J, Santoyo G \& Casey PJ 1996 Arachidonate and related unsaturated fatty acids selectively inactivate the guanine nucleotidebinding regulatory protein, $\mathrm{G}_{\mathrm{z}}$. Journal of Biological Chemistry $\mathbf{2 7 1}$ 2949-2954.

Hannigan GE \& Williams BRG 1991 Signal transduction by interferon$\alpha$ through arachidonic acid. Science 251 204-207.

Houslay MD \& Adams DR 2003 PDE4 cAMP phosphodiesterases: modular enzymes that orchestrate signalling cross-talk, desensitization and compartmentalization. Biochemical Journal 370 1-18.

Hyland JH, Manns JC \& Humphrey WD 1982 Prostaglandin production by ovine embryos and endometrium in vitro. Journal of Reproduction and Fertility 65 299-304.

Jabbour HN \& Sales KJ 2004 Prostaglandin receptor signalling and function in human endometrial pathology. Trends in Endocrinology and Metabolism 15 398-404.

Kawabe J-i, Iwami G, Ebina T, Ohno S, Katada T, Ueda Y, Homcy CJ \& Ishikawa Y 1994 Differential activation of adenylyl cyclase by protein kinase C isoenzymes. Journal of Biological Chemistry 269 16554-16558.

Kennedy TG 1983 Prostaglandin $E_{2}$, adenosine $3^{\prime}: 5^{\prime}$-cyclic monophosphate and changes in endometrial vascular permability in rat uteri sensitized for the decidual cell reaction. Biology of Reproduction 29 1069-1076

Khan WA, Blobe GC \& Hannun YA 1995 Arachidonic acid and free fatty acids as second messengers and the role of protein kinase $\mathrm{C}$. Cellular Signalling 7 171-184.

Kiley S, Schaap D, Parker P, Hsieh L-L \& Jaken S 1990 Protein kinase C heterogeneity in $\mathrm{GH}_{4} \mathrm{C}_{1}$ rat pituitary cells. Characterization of a $\mathrm{Ca}^{2+}$-independent phorbol ester receptor. Journal of Biological Chemistry 265 15704-15712.

Lee JS \& Silvia WJ 1994 Cellular mechanisms mediating the stimulation of ovine endometrial secretion of prostaglandin F2 alpha in response to oxytocin: role of phospholipase A2. Journal of Endocrinology 141 491-496.

Lee H-C, Cai JJ \& Yu H 1994 Effect of protein kinase C on cyclic 3', 5' adenosine monophosphate-dependent phosphodiesterase in hypertrophic cardiomyopathic hamster hearts. Journal of Pharmacology and Experimental Therapeutics 270 1171-1176.

Lim H, Gupta RA, Ma W-g, Paria BC, Moller DE, Morrow JD, DuBois RN, Trzaskos JM \& Dey SK 1999 Cyclo-oxygenase-2-derived prostacyclin mediates embryo implantation in the mouse via PPAR $\delta$. Genes and Development 13 1561-1574.

Lin T-H, Lai H-L, Kao Y-Y, Sun C-N, Hwang M-J \& Chern Y 2002 Protein kinase $\mathrm{C}$ inhibits type $\mathrm{VI}$ adenylyl cyclase by phosphorylating the regulatory $\mathrm{N}$ domain and two catalytic $\mathrm{C} 1$ and $\mathrm{C} 2$ domains. Journal of Biological Chemistry 277 15721-15728.

Magness RR, Huie JM, Hoyer GL, Huecksteadt TP, Reynolds LP, Seperich GJ, Whysong G \& Weems CW 1981 Effect of chronic ipsilateral or contralateral intrauterine infusion of prostaglandin $E_{2}$ $\left(\mathrm{PGE}_{2}\right)$ on luteal function of unilaterally ovariectomized ewes. Prostaglandins and Medicine 6 389-401.

Marcus GJ 1981 Prostaglandin formation by the sheep embryo and endometrium as an indication of maternal recognition of pregnancy. Biology of Reproduction 25 56-64.

Michael AE \& Webley GE 1991 Prostaglandin F2 alpha stimulates CAMP phosphodiesterase via protein kinase $\mathrm{C}$ in cultured human granulosa cells. Molecular and Cellular Endocrinology 82 207-214.
Nakamura J, Okamura N, Usuki S \& Bannai S 2001 Inhibition of adenylyl cyclase activity in brain membrane fractions by arachidonic acid and related unsaturated fatty acids. Archives of Biochemistry and Biophysics 389 68-76.

Parent J, Villeneuve C \& Fortier MA 2003 Evaluation of the contribution of cyclooxygenase 1 and cyclooxygenase 2 to the production of $\mathrm{PGE}_{2}$ and $\mathrm{PGF}_{2 \alpha}$ in epithelial cells from bovine endometrium. Reproduction 126 539-547.

Payne JH \& Lamming GE 1994 The direct influence of the embryo on uterine $\mathrm{PGF}_{2 \alpha}$ and $\mathrm{PGE}_{2}$ production in sheep. Journal of Reproduction and Fertility 101 737-741.

Peterson JS, Tervit HR, Fairclough RJ, Hawick PG \& Smith JF 1976 Jugular levels of 13,14-dihydro-15-keto-prostaglandin F and progesterone around luteolysis and early pregnancy in ewes. Prostaglandins 12 551-558.

Popovici RM, Kao L-C \& Giudice LC 2000 Discovery of new inducible genes in in vitro decidualized human endometrial stromal cells using microarray technology. Endocrinology 141 3510-3513.

Reese J, Zhao X, Ma WG, Brown N, Maziasz TJ \& Dey SK 2001 Comparative analysis of pharmacologic and/or genetic disruption of cyclooxygenase- 1 and cyclooxygenase- 2 function in female reproduction in mice. Endocrinology 142 3198-3206.

Robinson RS, Mann GE, Lamming GE \& Wathes DC 1999 The effect of pregnancy on the expression of uterine oxytocin, oestrogen and progesterone receptors during early pregnancy in the cow. Journal of Endocrinology 160 21-33.

Ronco AM, Moraga PF \& Llanos MN 2002 Arachidonic acid release from rat Leydig cells: the involvement of $\mathrm{G}$ protein, phospholipase $\mathrm{A}_{2}$ and regulation of CAMP production. Journal of Endocrinology 172 95-104.

Sales KJ, Katz AA, Davis M, Hinz S, Soeters RP, Hofmeyr MD, Millar RP \& Jabbour HN 2001 Cyclooxygenase-2 expression and prostaglandin $E_{2}$ synthesis are up-regulated in carcinomas of the cervix: a possible autocrine/paracrine regulation of neoplastic cell function via EP2/EP4 receptors. Journal of Clinical Endocrinology and Metabolism 86 2243-2249.

Schroer K, Zhu Y, Saunders MA, Deng W-G, Xu X-M, Meyer-Kirchrath J \& Wu KK 2002 Obligatory role of cyclic adenosine monophosphate response element in cyclooxygenase- 2 promoter induction and feedback regulation by inflammatory mediators. Circulation 105 2760-2765.

Sheldrick ELR, Derecka K, Marshall E, Chin E, Wathes DC, Abayasekara DRE \& Flint APF 2006 Arachidonic acid and uterine cyclooxygenase-2. Reproduction Abstract Series No. 33 Abstr. 008.

Shinomura T, Asaoka Y, Oka M, Yoshida K \& Nishizuka Y 1991 Synergistic action of diacylglycerol and unsaturated fatty acid for protein kinase $\mathrm{C}$ activation: its possible implications. PNAS $\mathbf{8 8}$ 5149-5153.

Smith WL, Garavito RM \& DeWitt DL 1996 Prostaglandin endoperoxide $\mathrm{H}$ synthases (cyclooxygenases)- 1 and -2. Journal of Biological Chemistry 271 33157-33160.

Tang B \& Gurpide E 1993 Direct effect of gonadotropins on decidualization of human endometrial stromal cells. Journal of Steroid Biochemistry and Molecular Biology 47 115-121.

Tetsuka T, Kusano E, Takeda S, Homma S, Yoshida I, Ando Y \& Asano Y 1995 Activation of protein kinase C stimulates cAMP phosphodiesterase in rat renal collecting tubule. American Journal of Physiology 268 F808-F814.

Tierney EP \& Giudice LC 2004 Role of activin A as a mediator of in vitro endometrial stromal cell decidualization via the cyclic adenosine monophosphate pathway. Fertility and Sterility 81 (Suppl 1) 899-903.

Tseng L, Gao JG, Chen R, Zhu HH, Mazella J \& Powell DR 1992 Effect of progestin, antiprogestin, and relaxin on the accumulation of prolactin and insulin-like growth factor-binding protein-1 messenger ribonucleic acid in human endometrial stromal cells. Biology of Reproduction 47 441-450. 
Webb FTG 1977 Cyclic AMP and the preparation of the mouse uterus for implantation. Journal of Reproduction and Fertility 50 83-89.

Wilson JM, Zalesky DD, Looney CR, Bondioli KR \& Magness RR 1992 Hormone secretion by preimplantation embryos in a dynamic in vitro culture system. Biology of Reproduction 46 295-300.

Wu YL \& Wiltbank MC 2002 Transcriptional regulation of the cyclooxygenase-2 gene changes from protein kinase (PK) A- to PKC-dependence after luteinization of granulosa cells. Biology of Reproduction 66 1505-1514.

Yoshino O, Osuga Y, Hirota $Y$, Koga $K$, Yano T, Tsutsumi $O$ \& Taketani Y 2003 Akt as a posible intracellular mediator for decidualization in human endometrial stromal cells. Molecular Human Reproduction 9 265-269.

Zheng L, Zomerdijk TPL, van den Barselaar MT, Geertsma MF, van Furth R \& Nibbering PH 1999 Arachidonic acid, but not its metabolites, is essential for Fc $\gamma$ R-stimulated intracellular killing of Staphylococcus aureus by human monocytes. Immunology 96 90-97.

Zhou XL, Lei ZM \& Rao CV 1999 Treatment of human endometrial gland epithelial cells with chorionic gonadotrophin/luteinizing hormone increases the expression of the cyclooxygenase-2 gene. Journal of Clinical Endocrinology and Metabolism 84 3364-3377.

Received 18 September 2006

First decision 16 October 2006

Revised manuscript received 12 January 2007

Accepted 25 January 2007 